\title{
Free Glycerol Measurement
}

National Cancer Institute

\section{Source}

National Cancer Institute. Free Glycerol Measurement. NCI Thesaurus. Code C100448.

The determination of the amount of free glycerol present in a sample. 